\title{
Effects of Educational Fundings on Retention and Dropout of Students in Public Secondary Schools in Seme Sub-County, Kenya
}

\author{
Opiyo Festus Omolo ${ }^{1}$ James Ochieng Sika ${ }^{2} \quad$ Maureen Ole $^{2}$ \\ 1.Department of Education Management and Foundations, Maseno University, Kenya \\ 2. Department of Education Management and Foundations, Maseno University, \\ P.O.Box Private Bag, Maseno, Kenya
}

\begin{abstract}
Kenya government has initiated a number of education investment fundings such as Free Tuition Secondary Education, Constituency Development Fund and District Education Board Bursary in secondary schools in an attempt to promote retention and reduce dropout rate among the students. However,the national dropout rate of students in secondary schools in Kenya was 42,272 (7.8 percent) and retention rate was 419,608 (76.7 percent). In Seme Sub-County, the proportion of 16 and 17 year old without access to education was 2,257 (9.1 percent) of the total number of secondary school going age 5,883 (26.1 percent) dropped out without completing secondary school. The purpose of this study was determine retention and drop-out rate of students in public secondary schools in Seme Sub County. The study adopted descriptive survey research design. All the thirty (30) public secondary schools in the Seme Sub-County were included in the study. The study found that there was high retention rate among the students and low dropout rate because of the availability of various government education educational funding's. Similarly, the number of students who dropped out of school due to lack of school fees between 2009 to 2013 had dropped, with most of the school principals registering less than $25 \%$ of dropout rate.
\end{abstract}

Keywords: Bursary; Funding's: Dropouts rates; Retention Rates

DOI: $10.7176 / \mathrm{JEP} / 10-12-12$

Publication date: April $30^{\text {th }} 2019$

\subsection{Introduction and Background}

Despite many policies and strategies developed to enhance a smooth transition rate in school there are still some students who withdraw from school prematurely. The Universal Declaration of Human Rights, Article 26, for instance states categorically that everyone has the right to education (UNESCO, 1998). To achieve this, the Kenya government laid down policies and allocated money in the National budget for provision of education to her people (MOEST, 2005). For instance, the Kenyan government has put in place several intervention measures which have been incorporated in its several initiatives and policies such as Free Tuition Secondary Education Funding's (FTSF), Constituency Development Fund (CDF) and District Education Board Bursary (DEBB).

However, the influence of these interventions and policies on retention and dropout rate among the secondary school students in Kenya is still not clear. Study conducted by Mellen (2004) on the impact of CDF on Equity in financing secondary education in Nyamira District. The study was intended to determine the percentage of CDF allocated to less advantaged group, as compared to the total CDF allocation in 2003 - 2007 and to Determine whether CDF has increased access in secondary education for children of less advantaged families and determine whether the financing level of needs of different schools guides CDF allocation to schools in order to promote equity. However, the study failed to look at other initiatives such as FTSE, CDF and DEBB, which the present study sought to fill.

In Kenya, as in other countries, the provision of quality education and relevant training to all is the key determinant for achieving the national development agenda and the realization of the millennium development goals (MDGs) (Kirigo, 2008). The government of Kenya has therefore focused its main attention on formulating different levels of education fundings. For instance, the introduction of both the free primary education and free tuition secondary education, secondary school cost-sharing policy and government funding such as CDF, BUSARY, LATIF are some of the government initiatives towards creating open access to education for all citizens and also to cub repetition and dropout of students in secondary schools. However retention and dropout still remains a challenge in most secondary schools in Kenya (Ministry of Education, 2012).

In 2013 , the national average for dropout rates was $7.8 \%(42,272)$ and from this percentage there was $2.2 \%$ $(13,333)$ and $6.6 \%(40,000)$ for boys and girls respectively. Against this, the main urban centres were better off with an average dropout rate of $4.3 \%(26,060)$. The incidence of dropping out or non-enrolment has been on the rise attributably to a large extent to the Structural Adjustment Program (SAP) which eroded the economic capacity of most families, thus rendering them unable to meet the education costs of their children (MOEST, 2013). The enrolment in the entire Formal Education Programs according to Republic of Kenya (2014) is about eight million which is about a quarter of the total population where secondary education constitutes a consolidation and transition between primary education and higher education and training and the world of work. 


\subsection{Statement of the Problem}

According to 2009-2013 report by Kenyan Ministry of Education on Seme Sub-County, the proportion of 16 and 17 year olds without access to education is $9.1 \%(2,257)$ and of those who attend public primary school, $26.1 \%$ $(5,883)$ drops out without completing secondary school. The ministry therefore recommends that this figure should be reduced if not eliminated for any meaningful education development to take place in the sub-county.

Table1: Secondary School Dropout Rate (2013)

\begin{tabular}{lll}
\hline Sub-Counties & Number & Percentage \\
\hline Gem & 4,425 & 25.3 \\
Rarieda & 4,565 & 24.7 \\
Kisumu West & 4,824 & 21.4 \\
Seme & 5,883 & 26.1 \\
\hline
\end{tabular}

Data from the Ministry of education, science and technology (MOEST) 2013

Table 1 reveals that comparatively, the dropout rate in Seme sub-county and that of the neighboring sub-counties is relatively high, despite the availability of various government education funding's. It is against this background that the present study intends to investigate Public Funding's and their influence on students' retention and dropout in public secondary schools in Seme Sub-County

\subsection{The Objectives Guiding the Study}

The study was guided by the following specific research objectives to;

i. Determine the retention and dropout rates of students in public secondary schools in Seme SubCounty.

ii. Establish the relationship between educational funding's and students' retention and dropout rate in Seme Sub-County

\subsection{Literature Review}

Students' retention and drop out, from school is a great concern for any government or society. In Canadian education system, the country's measurement of the status dropout rate is the percentage of 16-24 year olds who are not enrolled in school and have not earned a high school credential. This rate is different from the event dropout rate and related measures of the status completion and average freshman completion rates. The status high school dropout rate in 2009 was $8.1 \%$ (World Bank, 2006)

In Kenya, Okumu (2005) points out that both in Kwale and Nairobi, respondents of situation analysis survey, gave poverty as the most important factor for students dropping out of school (33 percent and 64 percent respectively). In Nairobi 37 percent of the respondents indicated that they would send their children to school in case of economic crunch. Report by MOE (2007) indicates that 58\% of the Kenyan population is living below the poverty line. This however leads to inability of the poor to meet education cost for their children. Murugi (2008) observed that over one million children are out of school in Kenya due to poor backgrounds. Some have been forced to drop out of school to earn a living for their families due to rising poverty and also given that they cannot meet the cost of education.

Mwawughanga, (2008) observed that dropout and repetition appear to be the most common problem among students from low socio-economic background and more prevalent among females than males. However, the findings of these studies do not provide clearly on the intervention of Public Educational fundings for education sustainability of these students that are socio-economically deprived. Therefore, this forms one of the gaps filled by the present study.

Ngware, Onsomu, Muthaka and Kosimbei (2006) conducted a study to examine strategies for improving access to secondary education in Kenya. They concluded that persistently, low participation rates from low income households indicates that the bursary fund has limited impact on ensuring that the beneficiaries are adequately supported for a full cycle. Consequently, they proposed that the government initiative in decentralizing and reviewing bursary funds management to constituency level should be closely monitored. Furthermore, they suggest that there is need to address income inequalities in the society, and that a special assistance scheme and preferential policies should be developed to target vulnerable groups such as students from marginalized communities, those with special needs and orphaned

Orodho and Njeru (2003) and Mellen (2004) also carried out researches on government bursary. From the results of the studies the government bursary fund is yet to achieve its main objective of ensuring access and quality education. However, two studies by Ngware et al (2006) did not provide conclusively the relationship between government education funding's and retention and dropout rate among the students in pubic secondary settings. 


\subsection{Research Design and Methodolgy \\ 3.1 Research Design}

Research design adopted for this study was descriptive survey research designs. This design is suitable for this study because they are used when the objective is systematic or description of facts and characteristics of a given population or sample of the population or area of interest factually and accurately. It is also suitable for this study given that it attempts to collect data from members of the population to determine its status with respect to one or more variables. Furthermore, it determines how things are at that point in time (Cohen, \&Manion, 2012).

\subsection{Area of Study}

Seme Sub-County is one of the newly founded Sub-Counties in Kisumu County and lies within longitudes $33^{\circ}$ $20^{\prime} \mathrm{E}$ and. $35^{\circ} 20^{\prime} \mathrm{E}$ and latitudes $0^{\circ} 20^{\prime}$ South and $0^{\circ} 50^{\prime}$ South. The Sub-County borders Siaya County to the west and Kisumu West Sub-County to the north, Rachuonyo Sub-County to the South and Kisumu Central Sub-County to the east.

\subsection{Study Population}

The study was done in all the 30public secondary schools in the Sub-County, implying that it involved all the 30 principals of these secondary schools as its major respondents. In addition, DEO official, CDF Secretary and DEBB Secretary was also be included in the study as key informants.

\subsection{Sample and Sampling Technique}

Saturated sampling technique was used to sample 30 public secondary schools in the sub-county. Purposive sampling was used to select those students who have benefited from Constituency Bursary Fund and District Education Board Bursary fund. Kombo and Delma (2006) observed that the purposive sampling method is the best technique for those who have benefited from a phenomenon

\subsection{Instruments for Data Collection}

Closed and open-ended questionnaires were used. The questionnaire was divided into two sections; the first section giving demographic information of the respondents and the next section containing semi-structured questions based on the thematic issues. Interview schedules were used to gather qualitative data from the DEO official, CDF Secretary and DEBB Secretary.

\subsection{RESEARCH RESULTS AND DISCUSSION}

4.1 Retention and Dropout Rate in Seme Sub-County

Responses were obtained from the school principals and result presented in the subsequent tables.

Table 2: Total number students who have been sent home for school fees more than thrice

\begin{tabular}{llllll}
\hline Years & Males & Percent. & Females & Percent & $\begin{array}{l}\text { Total number of students in the } \\
\text { school }\end{array}$ \\
\hline 2009 & 2,469 & 35.8 & 2,042 & 29.6 & 6,897 \\
2010 & 2,189 & 27.5 & 1,966 & 24.7 & 7,956 \\
2011 & 1,863 & 21.1 & 1,633 & 18.5 & 8,850 \\
2012 & 1,640 & 16.7 & 1,420 & 14.5 & 9,799 \\
2013 & 1,231 & 11.1 & 1,236 & 11.2 & 11,078 \\
\hline
\end{tabular}

The study found that out of the total students in $2009(\mathrm{n}=6897)$, only $35.8 \%$ and $29.6 \%$ of the males and female students respectively were sent home for school fees. However, this number has been constantly reducing and by 2013 , only $11.1 \%$ and $11.2 \%$ male and female students respectively have been sent home more than thrice. Decrease in the number of students sent home for school fees over the years could be explained by the existence of many government education educational fundings such as FTSE, CDF and DEBB. This finding was in line with the report documented by Mwawughanga, (2008) who also indicated that the introduction of both the free primary education and free tuition secondary education, secondary school cost-sharing policy and government funding such as CDF, BUSARY, LATIF are some of the government initiatives towards creating open access to education for all citizens and also to cub repetition and dropout of students in secondary schools. Table 3 shows the results of the number of students that have dropped out of school because of lack of school fees since 2009-2013. 
Table 3: The number of students that have dropped out of school since 2009-2013

\begin{tabular}{|c|c|c|c|c|c|}
\hline & \multicolumn{2}{|c|}{ Males } & \multicolumn{2}{|c|}{ Females } & \multirow{2}{*}{ Total number of students in the school } \\
\hline Years & No. & Perce. & No. & Perce. & \\
\hline 2009 & 1691 & $24.5 \%$ & 1863 & 27.0 & 6897 \\
\hline 2010 & 1402 & $17.6 \%$ & 1820 & 22.9 & 7956 \\
\hline 2011 & 1156 & $13.1 \%$ & 1722 & 19.5 & 8850 \\
\hline 2012 & 956 & $9.8 \%$ & 1653 & 16.9 & 9799 \\
\hline 2013 & 720 & $6.5 \%$ & 1540 & 13.9 & 11078 \\
\hline
\end{tabular}

The study found that in 2009, out of the total 6897 students, the number of male students who dropped out of school were $1691(24.5 \%)$, while their females were $n=1863(27.0 \%)$. This number reduced in the subsequent years with only $720(6.5 \%)$ male students dropping out of school, while females were $13.9 \%$. Generally, the dropout rate among the students in Seme sub county has been on the reducing trend and this could be explained by the existence of many government education educational funding's such as FTSE, CDF and DEBB. These findings contradicts those by KIPPRA (2008) who also found that given the relatively high fee levels in secondary schools, the set minimum bursary award was far below the fees charged, leading to some beneficiaries dropping out of school.

\subsection{Rating the effects of Educational Fundings on retention and dropout}

In rating the effects of educational fundings on retention and dropout. Figure1 shows the results.

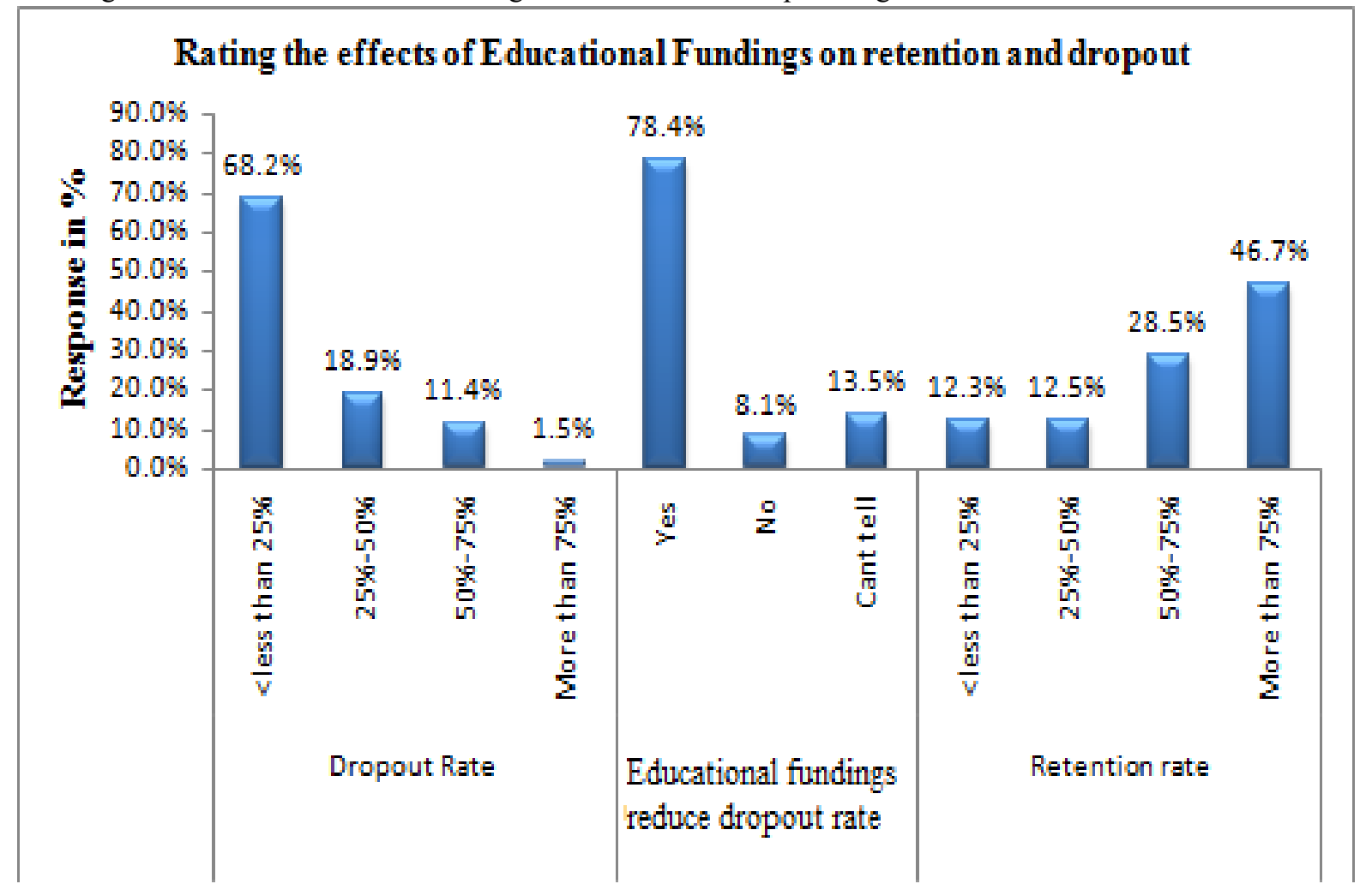

Figure 1: Rating the effects of Educational fundings on retention and dropout

According to the study findings in Figure 4.1, over two thirds of the respondents at $68.2 \%$ indicated that they had registered less than $25 \%$ of dropout rate, while only $1.5 \%$ indicated more than $75 \%$ dropout rate. Moreover, over three quarters of the respondents at $78.4 \%$ confirmed that Educational funding's reduced the dropout rate. Based on retention rate the study found that almost half of the respondents at $46.7 \%$ mentioned that their school registered more than $75 \%$ retention rate, while only $12.3 \%$ indicated less than $25 \%$ retention rate. Similarly, Misheck (2005) on a study of factors affecting students' access and participation in secondary schools found that the high cost of schooling was a major factor contributing to poor access and participation in secondary education in Meru central District

\subsection{Relationship between Education fundings and students' retention and dropout}

A five item 5-point likert scale was developed to measure various aspects of government education funding. Table 4 shows the response. 
Table 4: Opinion of the secondary school principals on Government education funding's and students' retention and dropout

\begin{tabular}{|c|c|c|c|c|c|c|}
\hline & & $\mathrm{SA}$ & $\mathrm{A}$ & $\mathrm{N}$ & $\mathrm{D}$ & SD \\
\hline lic Educa & $\mathrm{F}$ & 20 & 7 & 0 & 1 & 0 \\
\hline their & $\%$ & 71.4 & 25.0 & 0.0 & 3.6 & 0.0 \\
\hline I but were & $\mathrm{F}$ & 14 & 9 & 1 & 0 & 2 \\
\hline due & $\%$ & 50.0 & 32.1 & 3.6 & 0.0 & 7.1 \\
\hline ion funding policie & $\mathrm{F}$ & 18 & 8 & 1 & 1 & 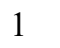 \\
\hline reter & $\%$ & 64.3 & 28.6 & 3.6 & 3.6 & 3.6 \\
\hline education funding influence positively the $r$ & $\mathrm{~F}$ & 16 & 10 & 0 & 1 & 0 \\
\hline their beneficiaries & $\%$ & 57.1 & 35.7 & 0.0 & 3.2 & 0.0 \\
\hline
\end{tabular}

The findings revealed that $96.4 \%$ cumulatively supported the statement that there students who depend entirely on Public Educational funding's for their school fees, with only 3.6\% refuting the statement. The study also found that there were students who had dropped out of school but were reinstated in school due availability of these educational funding's as confirmed by $82.1 \%$ of the respondents who agreed with the statement. Over two thirds of the respondents at $64.3 \%$ strongly agreed that the various governments education funding contributed to the retention of some students in their school, while only $7.2 \%$ of the students disputed the statement. Similarly, Oyugi (2010) on a study of Public Expenditure Tracking of Bursary Schemes in Kenya found that the major objective of the bursary scheme was to enable children from poor families access education.

\subsection{Relationship between Public Education Funding's and students' retention}

The relationship between Public Education funding's and students' retention among the learners was summated. Pearson moment correlation was run between the two variables with the findings presented in table 5

Table 5: Correlation Between Public Education Funding's And Students' Retention

\begin{tabular}{llll}
\hline & & Public education funding's & students' retention \\
\hline Public education fundings & Pearson Correlation & 1 & .845 \\
& Sig. (2-tailed) & & .040 \\
& $\mathrm{~N}$ & 28 & 28 \\
\multirow{3}{*}{ students' retention } & Pearson Correlation & .845 & 1 \\
& Sig. (2-tailed) & .040 & 28 \\
\cline { 2 - 4 } & $\mathrm{N}$ & 28 & \\
\hline
\end{tabular}

Source: Field data, $2016(\mathrm{p}=0.05)$

Pearson moment of correlation returned an $r$ value $=0.845$ with $p=0.05$ (at $95 \%$ confidence interval). This finding shows that there is a strong positive correlation which was statistically significant as $\mathrm{p}<0.05$. Thus there is steady positive increase in retention rate as the public education funding increases.

\subsection{Conclusion}

The study found that the number of students who have dropped out of school due to lack of school fees between 2009 to 2013 have been decreasing. This finding shows that there is a strong positive correlation which was statistically significant as $\mathrm{p}<0.05$.In establishing the relationship between Public education funding's and Dropout rate, the Pearson moment of correlation returned an $r$ value $=-0.618$ with $p=0.05$ (at $95 \%$ confidence interval). This finding shows that there is a strong negative correlation which was statistically significant as $p<0.05$. Thus when the Public education funding's increases, the dropout rate decreases.

\subsection{Recommendation}

The public should be adequately sensitized on the existence of various government education educational fundings including DEBB funds and when they are released to ensure that more students are able to apply for it. The allocations of the bursary to needy students should be done transparently and fairly to ensure that deserving students benefit from the scheme. The timing of the release of the various government education funds should be in line with the school academic calendar so that students can get the funds at the right time.

\subsection{About the authors}

1. Festus Opiyo Omolo: The corresponding author. Is a researcher at the department of education management and foundation where he is pursuing Ph.d in degree in Planning and Economics Education administration, Maseno University and Currently employed by teacher service commission, Kenya

2. James Ochieng Sika. Lecturer, Planning and Economics of Education, Department of Education Management and Foundation, Maseno University. Previously worked with ministry 
of education as quality assurance and standards officer and with teacher service commission.

3. Maureen Olel: Senior Lecturer, Planning and Economics of Education, Department of Education Management and Foundation, Maseno University. Previously a DAAD scholar

\subsection{REFERENCES}

Cohen, L. and Manion, L. (2012). Research Methods in Education, London: Rutledge

IPAR (2008) Public Expenditure Tracking of Secondary Education Bursary Scheme in Kenya. Nairobi.

KIPPRA (2007): Secondary School Education Bursary Fund (SEBF): URL accessed on 09/12/2011.http://www.kippra.org/Secondary.asp

Kirigo, S. M. (2008). An investigation into the effectiveness of bursary fund in enhancing retention of students in secondary schools in Mombasa District, Kenya. Unpublished M.Ed Project, Kenyatta University

Mellen, M. O. (2004). The role of Government bursary fund in enhancing the participation of girls in secondary education in Nyamira District, Kenya; Unpublished M.Ed Thesis, Kenyatta University.

MOEST, (2005). Education Sector Report 2005. Nairobi: Government Printer.

Mwawughanga, A. W. (2008). Impact of constituency bursary fund on girls' secondary education in Wundanyi Division of Taita District, Kenya. Unpublished MEd Project, Nairobi: Kenyatta University

Ngware, M, Onsomu, E. N ,Muthaka D \&Kosimbei, G (2006). Financing of Secondary Education in Kenya: Costs and Options. Institute for Public Policy Research and Analysis -Discuss Paper No. 55 Nairobi.

Njeru, EHC and Orodho A (2003) Secondary School Bursary Scheme Implementation and Challenges. IPAR Discussion Paper Series No. 036/2003.

Odebero, S. (2002). Bursary as a Method of Financing Secondary School Education in Busia District-Kenya. Unpublished M. Ed. Thesis Maseno University, Kenya

Okumu, B. (2005). The Situation of the Female Child. A case study of Nairobi. Nairobi: ANPPCAN

Onyango, G. A. (2001). Competencies Needed by Secondary School Headteachers and Influence on Pre-service Education. Unpublished PhD Thesis. Nairobi: Kenyatta University.

Orodho, J. A. and Njeru, E. H. N. (2003). Education Financing in Kenya: The Secondary School Bursary Scheme. Institute of Policy Analysis and Research - Discussion Paper No. 35. Nairobi

UNESCO, (2005). EFA. Global Monitoring Report: The Role of the Organization and Social Context of Schools. http://portal.org/education.

World Bank (2005): Priorities and Strategies for Education: A World Bank Review. Washington DC: The World Bank. 